Central Washington University

ScholarWorks@CWU

All Faculty Scholarship for the College of the Sciences

College of the Sciences

$11-23-2011$

\title{
Stratigraphic record of Holocene coseismic subsidence, Padang, West Sumatra
}

\author{
Tina Dura \\ University of Pennsylvania \\ Charles M. Rubin \\ Central Washington University \\ Harvey M. Kelsey \\ Humboldt State University \\ Benjamin P. Horton \\ University of Pennsylvania \\ Andrea Hawkes \\ Woods Hole Oceanographic Institution
}

See next page for additional authors

Follow this and additional works at: https://digitalcommons.cwu.edu/cotsfac

Part of the Geology Commons, Geophysics and Seismology Commons, Stratigraphy Commons, and the Tectonics and Structure Commons

\section{Recommended Citation}

Dura, T., C. M. Rubin, H. M. Kelsey, B. P. Horton, A. Hawkes, C. H. Vane, M. Daryono, C. G. Pre, T. Ladinsky, and S. Bradley (2011), Stratigraphic record of Holocene coseismic subsidence, Padang, West Sumatra, J. Geophys. Res., 116, B11306, doi:10.1029/2011JB008205.

This Article is brought to you for free and open access by the College of the Sciences at ScholarWorks@CWU. It has been accepted for inclusion in All Faculty Scholarship for the College of the Sciences by an authorized administrator of ScholarWorks@CWU. For more information, please contact scholarworks@cwu.edu. 
Authors

Tina Dura, Charles M. Rubin, Harvey M. Kelsey, Benjamin P. Horton, Andrea Hawkes, Christopher H. Vane, Mudrik Daryono, Candace Grand Pre, Tyler Landinsky, and Sarah Bradley 


\title{
Stratigraphic record of Holocene coseismic subsidence, Padang, West Sumatra
}

\author{
Tina Dura, ${ }^{1}$ Charles M. Rubin, ${ }^{2,3}$ Harvey M. Kelsey, ${ }^{4}$ Benjamin P. Horton, ${ }^{1,3}$
}

Andrea Hawkes, ${ }^{5}$ Christopher H. Vane, ${ }^{6}$ Mudrik Daryono, ${ }^{2}$ Candace Grand Pre, ${ }^{1}$ Tyler Ladinsky, ${ }^{4}$ and Sarah Bradley ${ }^{7}$

Received 5 January 2011; revised 10 August 2011; accepted 16 September 2011; published 23 November 2011.

[1] Stratigraphic evidence is found for two coseismic subsidence events that underlie a floodplain $20 \mathrm{~km}$ south of Padang, West Sumatra along the Mentawai segment $\left(0.5^{\circ} \mathrm{S}-0.3^{\circ} \mathrm{S}\right)$ of the Sunda subduction zone. Each earthquake is marked by a sharp soil-mud contact that represents a sudden change from mangrove to tidal flat. The earthquakes occurred about 4000 and 3000 cal years B.P. based on radiocarbon ages of detrital plant fragments and seeds. The absence of younger paleoseismic evidence suggests that late Holocene relative sea level fall left the floodplain too high for an earthquake to lower it into the intertidal zone. Our results point to a brief, few thousand year window of preservation of subsidence events in tidal-wetland stratigraphic sequences, a result that is generally applicable to other emergent coastlines of West Sumatra.

Citation: Dura, T., C. M. Rubin, H. M. Kelsey, B. P. Horton, A. Hawkes, C. H. Vane, M. Daryono, C. G. Pre, T. Ladinsky, and S. Bradley (2011), Stratigraphic record of Holocene coseismic subsidence, Padang, West Sumatra, J. Geophys. Res., 116, B11306, doi:10.1029/2011JB008205.

\section{Introduction}

[2] The closely spaced failures of the Sunda megathrust in 2004 and 2005 raised the possibility that the stresses imposed by these earthquakes have brought the megathrust immediately to the south, the Mentawai segment, closer to failure (Figure 1a) [Nalbant et al., 2005; Natawidjaja et al., 2007; Sieh et al., 2008]. Sequential uplift and tilt recorded in the corals of the outer arc islands overlying the Mentawai segment provide evidence for great earthquakes in A.D. 1797 $\left(\mathrm{M}_{\mathrm{W}}\right.$ 8.5-8.7) and A.D. $1833\left(\mathrm{M}_{\mathrm{W}}\right.$ 8.6-8.9) [Natawidjaja et al., 2006; Briggs et al., 2006]. The coral studies along with historical records of shaking and tsunami inundation at Padang (Figure 1a) suggest that all or most of the interface between $1^{\circ} \mathrm{S}$ and $5^{\circ} \mathrm{S}$ ruptured during these great earthquakes [Newcomb and McCann, 1987; Zachariasen et al., 1999, 2000; Natawidjaja et al., 2006]. Composite forward models show coseismic uplift of the outer arc islands of $\sim 1 \mathrm{~m}$ in 1797 and $\sim 3 \mathrm{~m}$ in 1833, and subsidence of the adjacent

\footnotetext{
${ }^{1}$ Sea Level Research, Department of Earth and Environmental Science, University of Pennsylvania, Philadelphia, Pennsylvania, USA.

${ }^{2}$ Department of Geology, Central Washington University, Ellensburg, Washington, USA.

${ }^{3}$ Earth Observatory of Singapore, Nanyang Technological University, Singapore.

${ }^{4}$ Department of Geology, Humboldt State University, Arcata, California, USA.

${ }^{5}$ Woods Hole Oceanographic Institute, Woods Hole, Massachusetts, USA.

${ }^{6}$ British Geological Survey, Nottingham, UK.

${ }^{7}$ Department of Earth Sciences, University of Bristol, Bristol, UK.

Copyright 2011 by the American Geophysical Union. 0148-0227/11/2011JB008205
}

coastline near Padang of $\sim 1 \mathrm{~m}$ in 1797 and $\sim 1.5 \mathrm{~m}$ in 1833 [Natawidjaja et al., 2006; Sieh et al., 2008]. The tendency of the coastline of West Sumatra to coseismically subside is supported by GPS observations from the 2005 Nias earthquake $\left(\mathrm{M}_{\mathrm{W}} 8.7\right)$ that document $1 \mathrm{~m}$ of subsidence landward of the trench [Briggs et al., 2006].

[3] Recent studies show that sufficient strain has accumulated on the Mentawai segment since the 1797 and 1833 events to produce a $\mathrm{M}_{\mathrm{W}}>8.0$ earthquake, which would affect the coast of West Sumatra and the provincial capital of Padang (Figure 1a) [Nalbant et al., 2005; Sieh et al., 2008; Bürgmann, 2009]. Indeed, the 30 September 2009 $\mathrm{M}_{\mathrm{W}} 7.6$ earthquake near Padang and the 25 October 2010 $M_{W} 7.7$ earthquake and tsunami that affected the Mentawai Islands highlight the seismic risk along West Sumatra, although neither earthquake relieved the strain accumulated along the 1797 and 1833 rupture patches [McCloskey et al., 2010].

[4] Paleogeodetic evidence from fringing coral reefs directly above the locked part of the Sunda megathrust have produced a robust record of coseismic uplift along the Mentawai segment during ruptures of the last thousand years [Zachariasen et al., 1999; Natawidjaja et al., 2006; Sieh et al., 2008], but this method can only be applied to areas with coralline coasts. Here, adapting a strategy that has been applied for over 30 years [Ovenshine et al., 1976; Combellick, 1986; Atwater, 1987; Nelson et al., 1996; Atwater and Hemphill-Haley, 1997; Kelsey et al., 2002; Hawkes et al., 2011] we use subsidence stratigraphy as an aid in assessing Holocene earthquake recurrence on the coseismically subsiding coastline adjacent to the Mentawai segment of the megathrust. On coastlines with net Holocene submergence, the stratigraphic record reflects the response of Earth's 


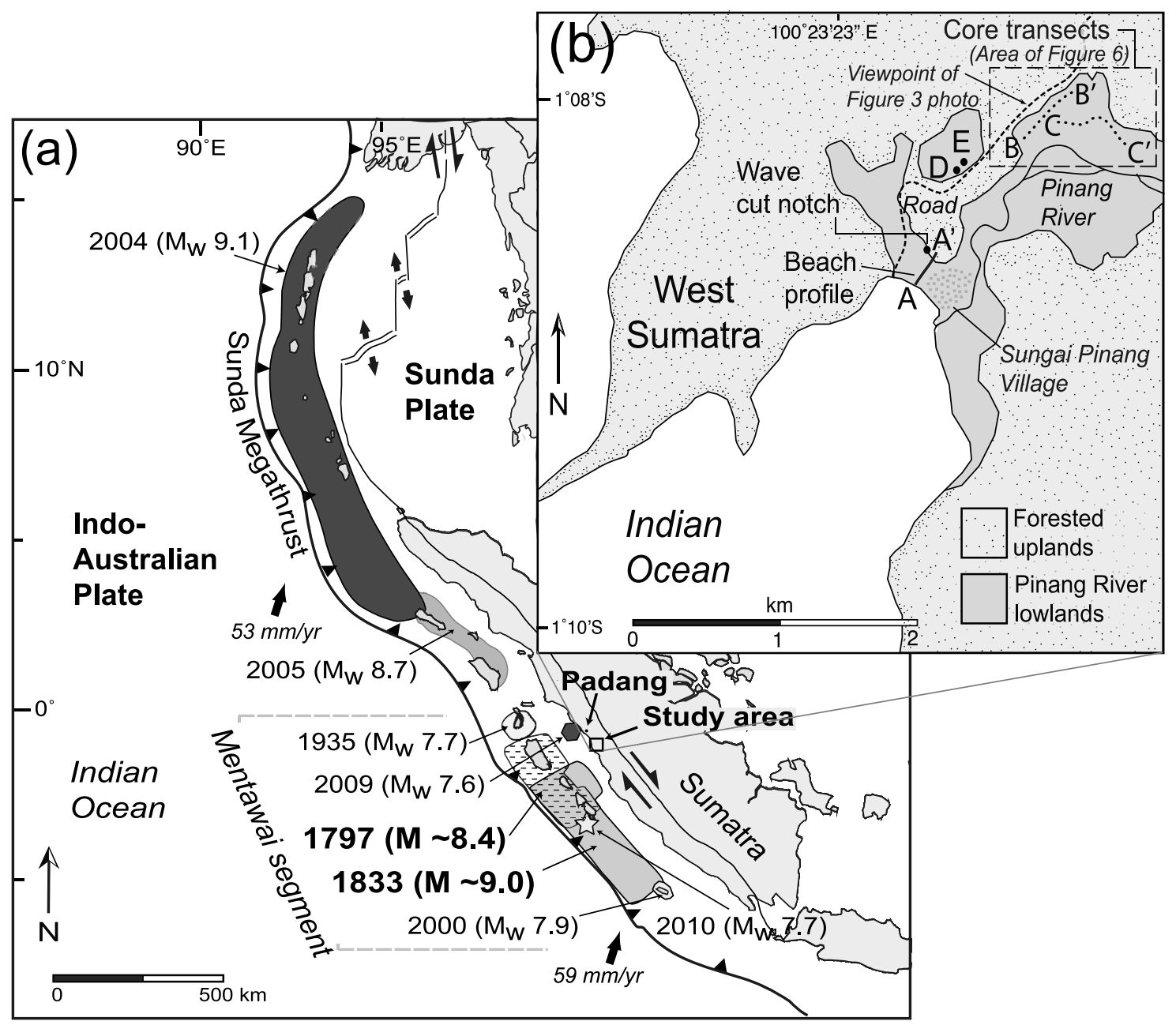

Figure 1. (a) Previous ruptures along the Sunda megathrust [Lay et al., 2005; Briggs et al., 2006; Subarya et al., 2006]. The extent of the Mentawai segment of the megathrust is shown by the bracketed dashed lines. The 1797 and 1833 rupture patches overlap and are shown by a stippled pattern (1797) and light gray shading (1833). (b) Study region $20 \mathrm{~km}$ south of the Western Sumatran capital of Padang. Location of beach profile, A- $\mathrm{A}^{\prime}$ (shown in detail in Figure 4a). Cores were logged in a $120,000 \mathrm{~m}^{2}$ rice paddy along two core transects, $\mathrm{B}-\mathrm{B}^{\prime}$ and $\mathrm{C}-\mathrm{C}^{\prime}$. The Pinang River borders the study area to the south and the highlands border the study area to the north. Area of Figure 6 is shown by dashed line outlining the core transects.

surface to the earthquake deformation cycle. The earthquake cycle is represented by a unique series of instantaneous relative sea level (RSL) rises (coseismic land subsidence) interspersed between extended periods of RSL fall (interseismic land uplift). When this cycle is accompanied by regional RSL rise due to eustatic or isostatic processes, the accommodation space created by the net submergence of the coastline allows for a suite of buried soil-mud couplets to form in low-energy coastal wetland environments (Figure 2). The application of subsidence stratigraphy has produced geologic evidence of paleoearthquakes in the tidal wetlands of Cascadia [e.g., Atwater, 1987; Atwater and HemphillHaley, 1997; Nelson et al., 2008; Hawkes et al., 2011], Alaska [e.g., Ovenshine et al., 1976; Combellick, 1986; Hamilton and Shennan, 2005], Chile [Cisternas et al., 2005], Japan [e.g., Sawai et al., 2004], and New Zealand [e.g., Hayward et al., 2004].
[5] Coastlines with net Holocene emergence (i.e., coasts with a mid-Holocene sea level highstand) also have the potential to preserve RSL changes representative of the earthquake deformation cycle, but the lack of accommodation space during late Holocene RSL fall makes preservation more difficult. On prograding emergent coastlines, tsunami deposits draped over beach-ridge and inset terrace sequences provide evidence of regional earthquakes in Sumatra [Monecke et al., 2008] and Thailand [Jankaew et al., 2008]. Records of localized coseismic subsidence and accompanying RSL rise (buried soil-mud couplets) on emergent coastlines are scarce, and where discovered, often fragmentary [Nelson et al., 2009]. In this paper, we present a brief record of coseismic subsidence preserved in the stratigraphy of a coastal freshwater lowland with net Holocene emergence and place it in the context of the regional record of Holocene RSL change (Figure 1b). Our record illustrates 


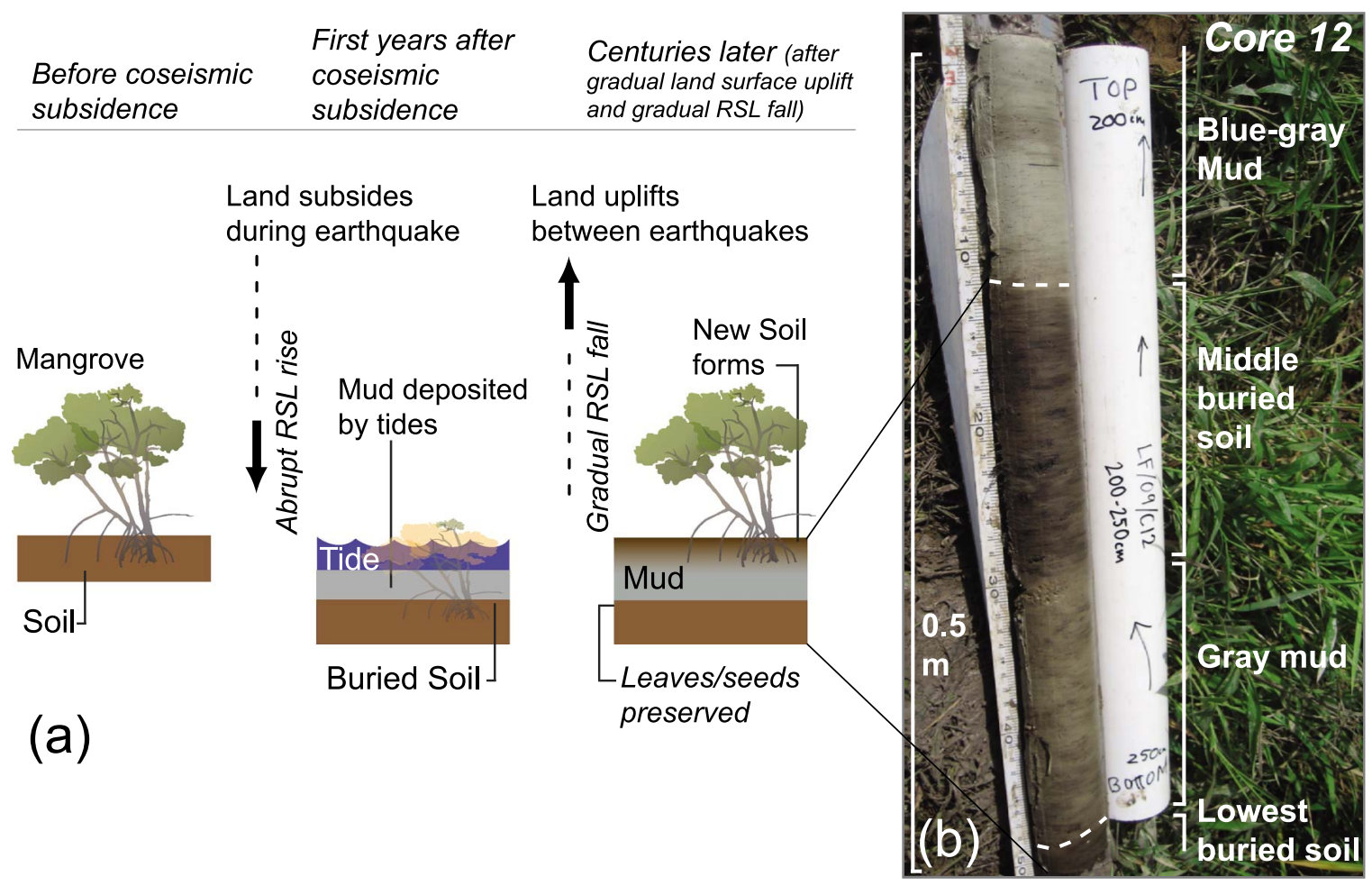

Figure 2. (a) Schematic depiction of the coseismic subsidence of a mangrove covered coastline and subsequent soil burial by tidal mud. Figure modified from Atwater and Hemphill-Haley [1997], mangrove image from Tracey Saxby, IAN Image Library (ian.umces.edu/imagelibrary/displayimage-4579.htp.

(b) Core 12 from the Sungai Pinang study area.

the limited preservation window for subsidence events along the Mentawai segment of the subduction zone.

\section{Setting}

[6] Sumatra sits on top of the Sunda Plate that lies adjacent to the subducting Indo-Australian Plate (Figure 1a). Recent GPS geodesy shows that islands southeast of Sumatra, at Java, are converging with the Indo-Australian Plate at a rate of $59 \mathrm{~mm} / \mathrm{yr}$ [Michel et al., 2001; Bock et al., 2003; Prawirodirdjo and Bock, 2004]. Near Sumatra, the convergence is oblique to the trench and relative plate motions are partitioned into nearly trench perpendicular convergence along the megathrust at $53 \mathrm{~mm} / \mathrm{yr}$ and trench parallel, dextral slip along the inland Sumatran fault at $\sim 11-$ $28 \mathrm{~mm} / \mathrm{yr}$ [Genrich et al., 2000; Sieh and Natawidjaja, 2000; Subarya et al., 2006]. Based on satellite imagery and field relations, we found no evidence of Holoceneactive upper plate faulting and have no reason to suspect that these faults are responsible for coastal subsidence.

[7] Our study focuses on a coastal freshwater lowland $20 \mathrm{~km}$ south of the provincial capital of West Sumatra, Padang (Figure 1b). The study area, $1 \mathrm{~km}$ inland from the coastal village of Sungai Pinang, is located on an emergent floodplain that is now transected by the modern Pinang River (Figure 3). The area lies between 1 and $3 \mathrm{~m}$ above modern mean tidal level (MTL). The Sungai Pinang coastal floodplain is ideal for the preservation of subsidence stratigraphy because it is a low-energy environment protected from storm waves by coastal headlands to the north that create an embayment at the mouth of the Pinang River. Surveys determined that the modern tidal range at Sungai Pinang is about $1 \mathrm{~m}$.

[8] Comparable modern intertidal environments to the buried soil-mud couplets are absent at Sungai Pinang and elsewhere in West Sumatra because of extensive land reclamation by European colonization and more recently by clearance for aquaculture [Whitten et al., 1997]. However, studies on the modern mangrove environments of Sulawesi, Indonesia, which also have a microtidal regime, have shown mangrove plants extending hundreds of meters inland from the coast [Horton et al., 2007; Engelhart et al., 2007]. Mangroves can grow from mean tide level (MTL) to highest astronomical tide (HAT) [Grindrod, 1985, 1988; Ellison, 1989, 2005; Kamaludin, 1993; Horton et al., 2005], although they do not produce enough organic matter at their seaward fringe for a peat to accumulate [Matthijs et al., 1999; Engelhart et al., 2007]. In modern intertidal environments, the highest percentage of organics is found between mean high water (MHW) and HAT (which is a range of $0.5 \mathrm{~m}$ in Sungai Pinang) dominated by the mangrove species Rhizophora, Ceriops, and Avecennia [Grindrod, 1985, 1988; Ellison, 1989, 2005; Kamaludin, 1993; Matthijs et al., 1999; Horton et al., 2007; Engelhart et al., 2007].

\section{Methods}

\subsection{Lithostratigraphy}

[9] The sudden submergence and burial of vegetated wetland soils results in a distinctive lithostratigraphic 


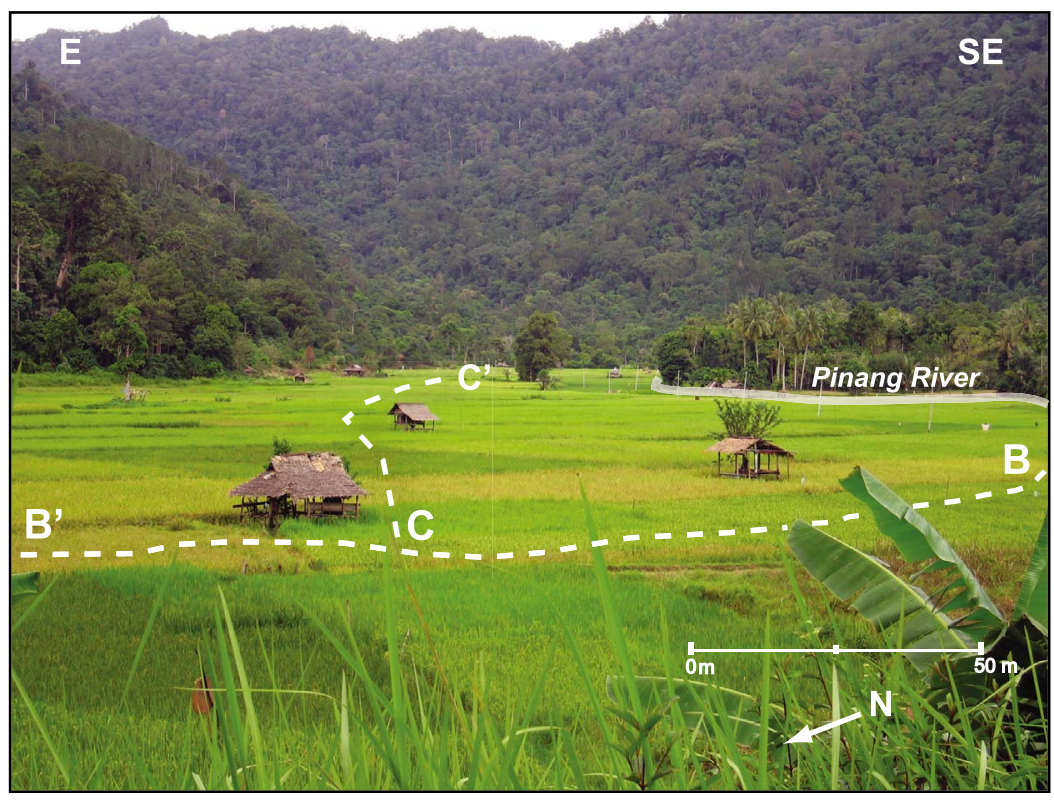

Figure 3. Photograph showing the two coring transects in the Sungai Pinang lowlands. Photograph was taken from the road looking east-southeast over the study area (location shown on Figure 1b).

sequence that provides evidence for repeated plate boundary earthquakes. We infer that if the Mentawai segment of the Sunda Megathrust has ruptured repeatedly in the Holocene, coastal wetland sites such as Sungai Pinang subsided coseismically and should have preserved recurring, abrupt RSL change as a series of buried soils.

[10] We examined the stratigraphy in 20 gouge cores along two cross-section lines, each about $200 \mathrm{~m}$ long (Figure 3). Cores were collected with a $1 \mathrm{~m}$ long, $25 \mathrm{~mm}$ diameter, half-cylinder gouge corer. The cores were logged to a depth of 3-5 m along the transects in order to test for lateral continuity of stratigraphic horizons. In addition, we logged three cores in a lowland $500 \mathrm{~m}$ seaward from the study area. Soils were described in the field using the Troels-Smith [1955] method for the description of organicrich sediment. In our investigation, the term "soil" refers to dark horizons with visible woody and herbaceous fragments and humified organic matter that made up at least $25 \%$ of the sedimentary unit. The overlying mud was distinguished by its lack of organic matter, a change in color to blue-gray (Gley2 8/5B) or gray (Gley2 8/5B) (Munsell Soil Color Chart, 2009) and a clay to silty clay mineral content. Using methods adapted from Kelsey et al. [2002], the soils were correlated among the 20 cores on the basis of depth below ground surface, lithostratigraphy, stratigraphic separation, and the thickness of sediment from the top of one buried soil to the next (Figure 4).

[11] The criteria used to identify soils buried by coseismic subsidence follow Nelson et al. [1996]: (1) a stratigraphic transition between soils and overlying mud that represents a paleoenvironmental change from mangrove to tidal flat or subtidal environments; (2) a sharp $(<1-3 \mathrm{~mm})$ contact separating the soils from the overlying mud, indicating a rapid change in the depositional environment; (3) lateral continuity of the soil horizons throughout the study area indicating that the RSL rise affected the entire coastal lowland; and (4) a $>20 \mathrm{~cm}$ thickness of the mud interval separating the soils, representing prolonged submergence of the coastline.

[12] We used a digital auto-level to establish core elevations and the height of wave cut notches (Figure 4a). All core sites and coastal profile locations were surveyed relative to each other with an error of $< \pm 5 \mathrm{~cm}$. We related these elevations to local mean tide level (MTL), determined by repeated surveys of local tidal variation.

\subsection{Geochemistry}

[13] We used stable carbon isotopic composition $\left(\delta^{13} \mathrm{C}\right)$ and the ratio of total organic carbon (TOC) to total nitrogen (C:N) in bulk-organic sediments to identify the transition of depositional environments from freshwater to brackish to marine [e.g., Wilson et al., 2005; Bouillon et al., 2008; Kemp et al., 2010; Ku et al., 2007; Lamb et al., 2006, 2007]. Based on data extrapolated from a study conducted on mangrove swamps in French Guiana (latitude $4^{\circ}$ ), $\delta^{13} \mathrm{C}$ of wood and leaves from mangrove environments have $\delta^{13} \mathrm{C}$ values of -30.1 to $-27.9 \%$, while $\mathrm{C}: \mathrm{N}$ ratios range from mean values close to 20 for leaves and 50 for wood [Marchand et al., 2005]. In contrast, organic material from algae and mangrove litter that falls on the tidal flat at the seaward extent of the mangrove swamp is typically ${ }^{13} \mathrm{C}$-enriched and yields $\delta^{13} \mathrm{C}$ values between -24 to $-10 \%$ and has low (>20) C:N ratios [Ambler et al., 1994; Bouillon et al., 2008]. There may be some overlap in $\delta^{13} \mathrm{C}$ due to plant type, sediment mixing, and decomposition [Lamb et al., 2007; Kemp et al., 2010].

[14] We analyzed $\delta^{13} \mathrm{C}$ and TOC for samples collected from buried soils and overlying muds in core 15. In this preliminary analysis, we sampled at $1 \mathrm{~cm}$ intervals above the upper buried soil and also within and above the lower two buried soils. Using the method of Kemp et al. [2010], sediment samples $(0.5 \mathrm{~g})$ were treated with 5\% HCL $(100 \mathrm{ml})$ for $18 \mathrm{~h}$, washed three times with deionized water $(500 \mathrm{ml})$, dried in an oven at $40^{\circ} \mathrm{C}$ overnight and milled to a fine 


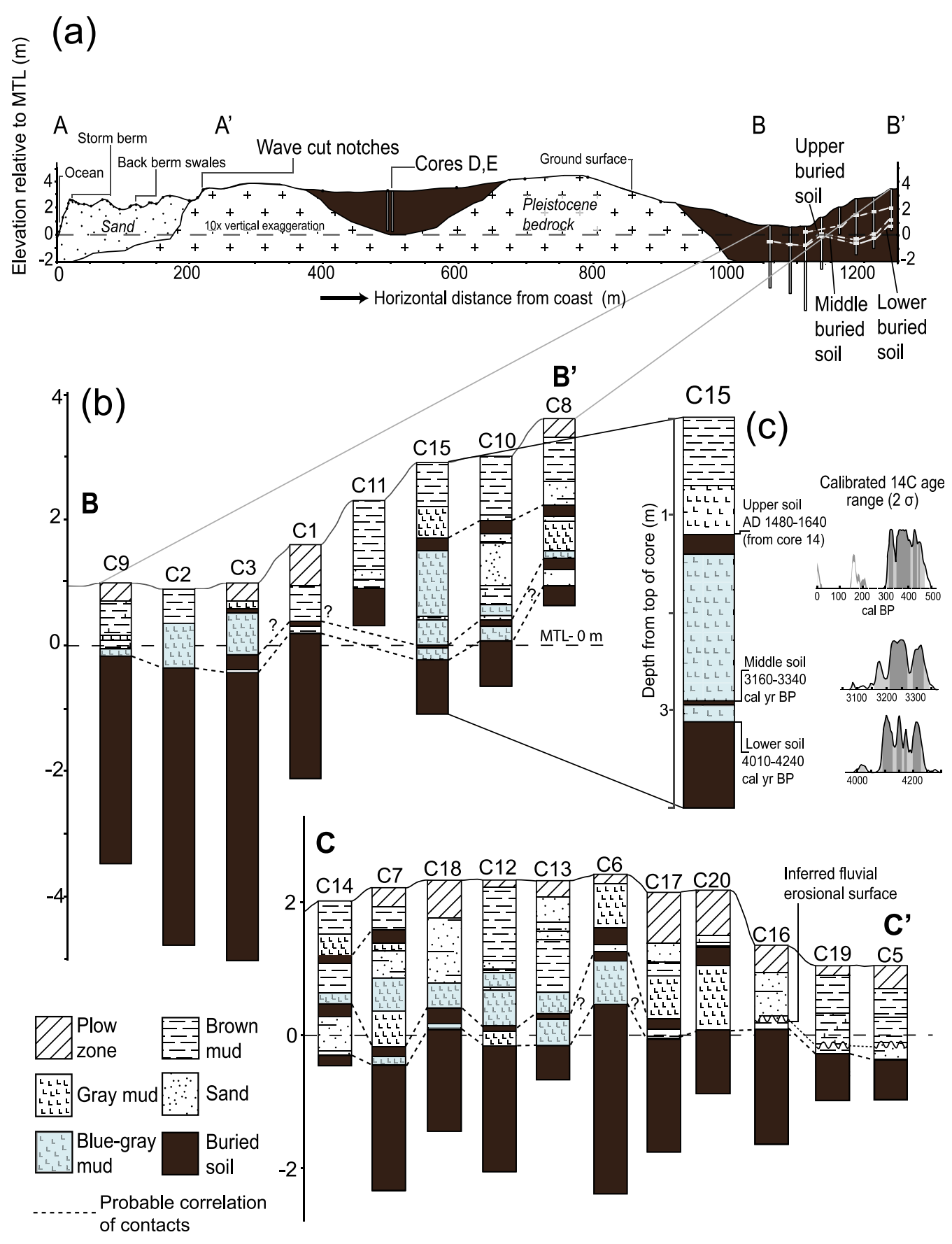

Figure 4. (a) Coast perpendicular profile including beach profile $\mathrm{A}-\mathrm{A}^{\prime}$ and coast perpendicular core transect $B-B^{\prime}$ (see Figure $1 \mathrm{~b}$ and Figure 3 for locations). Beach and core elevations are relative to mean tidal level (MTL). (b) The B-B' and $\mathrm{C}^{-\mathrm{C}^{\prime}}$ core transects include the simplified stratigraphy of cores with three soils highlighted: the lowest soil, middle soil, and upper soil. The dashed line shows inferred correlations between soils. (c) Detail of core 15 stratigraphic relations and probability density distributions for calibrated radiocarbon dates (ages were calibrated and errors were calculated using OxCal radiocarbon calibration software [Bronk Ramsey, 2009] with the IntCal04 data set of Reimer et al. [2004]).

powder. C:N ratios were analyzed on the same instrument; the ratios are calibrated through acetanilide standard. Replicate analysis of well-mixed samples indicated a precision of $+<0.1 \%$ ( $1 \mathrm{SD})$. All TOC and C:N values are expressed on a weight ratio basis and the $\mathrm{N}$ values used herein represent the combined total organic and inorganic content.

\subsection{Radiocarbon Dating}

[15] Plant macrofossils were collected from the upper few centimeters of the buried soils to provide maximum limiting radiocarbon ages of soil burial. To reduce the likelihood of analyzing detrital material that died a significant time before burial, we followed the methodology of Nelson et al. [1995] 
Table 1. Buried Soil Attributes and Criteria for Coseismic Burial ${ }^{\mathrm{a}}$

\begin{tabular}{lccc}
\hline & Upper Buried Soil & Middle Buried Soil & Lowest Buried Soil \\
\hline Attributes & & & \\
$\quad$ Elevation range of buried soil relative to MTL (m) & 0.6 to 2.2 & -0.2 to 1.4 & -0.5 to 0.9 \\
Number of cores that contain buried soil & 6 & 12 & 20 \\
Abruptness of soil/mud contact & Sharp $^{\mathrm{b}}$ & Sharp $^{\mathrm{b}}$ & Sharp $^{\mathrm{b}}$ \\
Average thickness of sediment overlying buried soil (m) & Modern sediment & 1.0 & 0.5 \\
Criteria For Coseismic Burial & $\mathrm{X}$ & $\mathrm{X}$ & $\mathrm{X}$ \\
Abrupt lithostratigraphic transition at soil/mud contact & $\mathrm{X}$ & $\mathrm{X}$ & $\mathrm{X}$ \\
Sharp soil/mud upper contact $(<1-3 \mathrm{~mm})$ & & $\mathrm{X}$ & $\mathrm{X}$ \\
Permanence of RSL rise $(>10 \mathrm{~cm}$ of mud overlies buried soil) & & $\mathrm{X}$ & \\
Lateral extent of soil/mud contact $\left(>100,000 \mathrm{~m}^{2}\right)$ & &
\end{tabular}

${ }^{\text {a}}$ Soil elevations were measured by leveling to geodetic benchmarks.

${ }^{\mathrm{b}}$ Sharp denotes stratigraphic transition over $<1-3 \mathrm{~mm}$.

and Kelsey et al. [2002] and only collected samples that were so delicate (e.g., seeds, leaf parts) that they would have been broken and made unidentifiable by significant transport or significant time.

[16] The timing of soil burial was calculated from calibrated radiocarbon dates. If two or more radiocarbon ages are available, we report the youngest age range as the closest approximation to soil burial. Radiocarbon ages were calibrated using OxCal radiocarbon calibration software [Bronk Ramsey, 2009] with the IntCal04 data set of Reimer et al. [2004]. Calibrated age ranges are shown with two standard deviations, where years 'before present' (B.P.) is years before A.D. 1950.

\section{Results}

[17] Elevated wave-cut notches $250 \mathrm{~m}$ inland have an elevation of 3.0-3.8 $\mathrm{m}$ above modern mean high tide (3.5$4.3 \mathrm{~m}$ above MTL) (Figure 4a). The main coring location was $>1 \mathrm{~m}$ above MTL and $1 \mathrm{~km}$ inland from the coast.

[18] Sediments in the Sungai Pinang coastal wetland consisted of interbedded soils and clastic deposits (Figure 2b). Eight of the 20 cores contained a complete sequence of buried soils, six contained only the middle and lowest buried soils, and the remaining six cores contained only the lowest buried soil. Of the 43 contacts observed between buried soils and overlying units, the majority of the contacts $(n=39)$ were sharp $(<3 \mathrm{~mm})$ (Table 1). We suggest that bioturbation is minimal due to the rapid deposition of sediment following coseismic subsidence. We did not observe a sandy deposit overlying the buried soils and hence did not document evidence of tsunami inundation. The sheltered estuarine setting of Sungai Pinang, which today is $>1 \mathrm{~km}$ inland of the embayment, likely precluded transport of tsunami sand to the study area. There was no evidence of additional buried soils seaward of our study area. Cores D and E, taken from a lowland $500 \mathrm{~m}$ from the modern shoreline, met core refusal at $\sim 3 \mathrm{~m}$ on a sand base and contained a sequence of mud and sand with traces of organics (Figure 4a).

[19] The lowest buried soil is the most laterally continuous and the thickest of the three soils. It is preserved in 19 of 20 cores with a range of $-0.5 \mathrm{~m}$ to $0.9 \mathrm{~m}$ MTL. The presence of mangrove derived woody organic matter within the lowest buried soil of core 15 is implied by low $\delta^{13} \mathrm{C}$ ranging from -28.3 to $-29.2 \%$, TOC values of $6.1-10.8 \%$ and elevated C:N values $>60$ (Figure 5). The youngest of three radiocarbon dates from woody and herbaceous fragments of the lowest buried soil in core 15 (Figure 4c) constrain the onset of soil burial to a maximum of 4010-4240 cal years B.P. (Table 2). The lowest buried soil is sharply overlain by a blue-gray to gray mud. We infer that the mud component represents more intertidal conditions with slightly higher $\delta^{13} \mathrm{C}$ values, lower TOC $(<0.5 \%)$ and a fall in C:N $(<13)$.

[20] The middle buried soil is the thinnest of the three soils and separated from the lowest buried soil by an average of $0.5 \mathrm{~m}$ of sediment. The elevation of the middle buried soil ranged from -0.2 to $1.4 \mathrm{~m}$ MTL. The thickness of the middle soil and its consistent separation from the lowest soil aided in correlation. The middle buried soil is present in both the $\mathrm{B}-\mathrm{B}^{\prime}$ core transect and the $\mathrm{C}-\mathrm{C}^{\prime}$ core transect but is not well preserved in lower elevation cores (cores 5, 16, and 19) near the Pinang River, which probably eroded the soil via channel migration. This erosion is also reflected in the anomalously low elevations of the lowest soil in cores near the river. The younger of two radiocarbon dates from woody and herbaceous fragments collected from core 15 constrain the timing of soil burial to a maximum of 3160 3340 cal years B.P. Similar to the lowest buried soil, the middle soil is overlain along a sharp contact by a blue-gray mud. An increase in marine conditions are indicated in the overlying mud by the geochemistry, which shows high $\delta^{13} \mathrm{C}$ values and low $\mathrm{C}: \mathrm{N}$ ratios.

[21] The upper buried soil is separated from the middle buried soil by an average of $1 \mathrm{~m}$ of sediment and is found with an elevation range of $0.6-2.2 \mathrm{~m}$ MTL. The upper buried soil is discontinuous. It is better preserved in cores with higher elevations distant from the Pinang River (Figure 6). The upper buried soil is difficult to identify because it lies close to the plow zone, but based on intact stratigraphy above the soil in cores $8,10,14$, and 15 we are confident in our correlation. The upper buried soil coincides with a rise in TOC values and variable $\mathrm{C}: \mathrm{N}$ and $\delta^{13} \mathrm{C}$ values $(-29.1$ to $-27.1 \%$ ), which suggests a return to a mangrove dominated environment. An increase in the influence of marine sourced organic matter, inferred from both elevated $\delta^{13} \mathrm{C}$ and diminished $\mathrm{C}: \mathrm{N}$ values, is found above the upper soil. Plant fragments from the upper buried soil in core 15 yielded two modern radiocarbon ages. An additional upper buried soil radiocarbon age calculated from seeds in core 14 yielded an age of 1480-1640 cal years A.D.

\section{Evidence for Plate Boundary Earthquakes}

[22] The stratigraphic record of the Sungai Pinang lowlands contains two buried soils (lowest and middle), that satisfy multiple criteria of Nelson et al. [1996] for the 


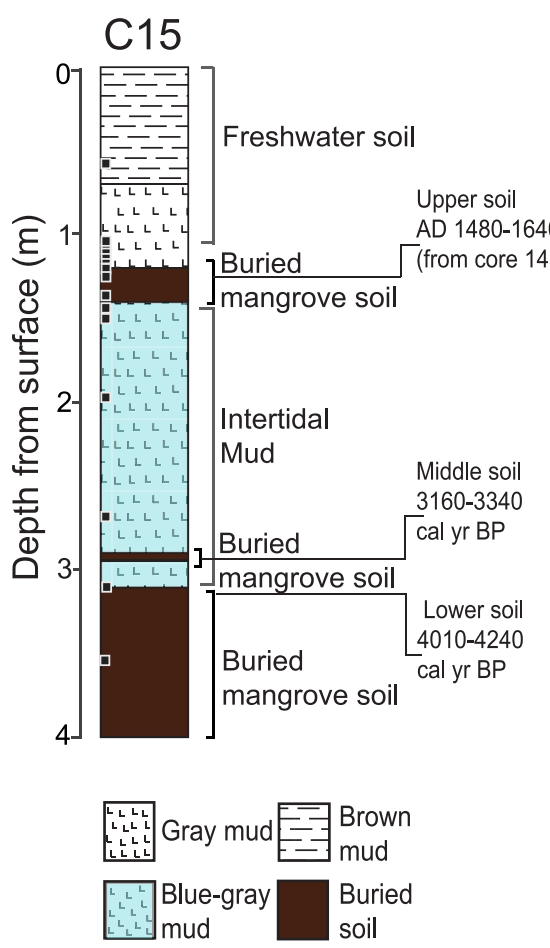

Figure 5. Results of preliminary geochemistry completed on core 15. Sampling locations shown by black squares on core. Low $\delta^{13} \mathrm{C}$ values and elevated C:N and TOC values suggest a brackish mangrove environment, while higher $\delta^{13} \mathrm{C}$ values and a decrease in $\mathrm{C}: \mathrm{N}$ and TOC values suggests an increase in the influence of marine sourced organic matter.

coseismic origin of soil burial (Table 1). The lateral continuity of the lowest and middle buried soil horizons indicates that the entire mangrove wetland (i.e., $120,000 \mathrm{~m}^{2}$ ) was affected by sudden rises in RSL.

[23] The properties of the two buried soils and of the overlying mud are similar throughout the Sungai Pinang lowland. The organic soils found in the stratigraphy of the study area suggest that the soils accumulated on the landward edges of the mangrove swamp that formerly covered the coastal lowland. Early to mid-Holocene gradual RSL rise along the coast of West Sumatra, similar to other regions of southeast Asia, allowed these soils to aggrade and create a thick mangrove soils, filling low-lying areas [Streif, 1979; Bosche, 1988; Somboon and Thiramongkol, 1992; Kamaludin, 1993; Horton et al., 2005]. The lowest and middle buried soils both have an elevation range of $\sim 1.5 \mathrm{~m}$ due to post-depositional processes such as compaction [Törnqvist et al., 2008], as well as original land surface relief [cf. Atwater, 1987]. Assuming the uniform burial of a mangrove surface with $\sim 1 \mathrm{~m}$ of relief suggests subsidence on the order of $1 \mathrm{~m}$ would have been required to lower these soils into tidal flat elevations. Similar subsidence values along the coastline of West Sumatra were modeled by Natawidjaja et al. [2006] and Sieh et al. [2008] for the great earthquakes of A.D. 1797 and 1833.

[24] The sharp contacts separating the lowest and middle buried mangrove soils from overlying mud provide further evidence that the soils were abruptly submerged during a sudden rise in RSL caused by coseismic subsidence of the coastline. Longer-term RSL changes from eustatic and/or

Table 2. Sungai Pinang Radiocarbon Age Determinations ${ }^{\mathrm{a}}$

\begin{tabular}{|c|c|c|c|c|c|}
\hline Buried Soil & Sample ID & ${ }^{14} \mathrm{C}$ Years B.P. ${ }^{\mathrm{a}}$ & $\begin{array}{c}\text { Calibrated }{ }^{14} \mathrm{C} \text { Age Range, } 2 \sigma^{\mathrm{b}} \\
\text { (Cal Years B.P.) }\end{array}$ & Date & Sample Material \\
\hline Upper & LF.09.15.110 & $135 \pm 30$ & $0-279$ & 11.30 .09 & Two detrital branches, lengths $=5 \mathrm{~mm}$ and $13 \mathrm{~mm}$ \\
\hline Upper & LF.09.15.111 & $165 \pm 25$ & $0-285$ & 11.30 .09 & Woody branch, $8 \mathrm{~mm} \times 1 \mathrm{~mm} \times 0.5 \mathrm{~mm}$ \\
\hline Upper & LF.09.14.84.5 & $330 \pm 30$ & $1480-1640 \mathrm{AD}$ & 4.19 .10 & Seeds \\
\hline Middle & LF.09.15.292 & $3030 \pm 30$ & $3160-3340$ & 4.19 .10 & Small detrital wood fragments \\
\hline Middle & LF.09.15.290A & $3570 \pm 30$ & $3770-3940$ & 11.30 .09 & Small detrital wood fragments \\
\hline Lower & LF.09.15.326 & $3780 \pm 30$ & $4010-4240$ & 11.30 .09 & $1 \times 2 \mathrm{~cm}$ horizontal wood fragment \\
\hline Lower & LF.09.15.327 & $3900 \pm 35$ & $4190-4420$ & 11.30 .09 & Complete branchlet \\
\hline Lower & LF.09.15.330 & $4410 \pm 35$ & $4860-5270$ & 11.30 .09 & 5 detrital wood fragments \\
\hline
\end{tabular}

${ }^{\mathrm{a}}$ Samples were analyzed at the National Ocean Sciences Accelerator Mass Spectrometry Facility (NOSAMS) in Woods Hole, MA.

${ }^{b}$ Radiocarbon ages reflect radiocarbon years before present $\left({ }^{14} \mathrm{C}\right.$ cal years B.P.) where present is A.D. 1950. Ages were calibrated and errors were calculated using OxCal radiocarbon calibration software [Bronk Ramsey, 2009] with the IntCal04 data set of Reimer et al. [2004]. 


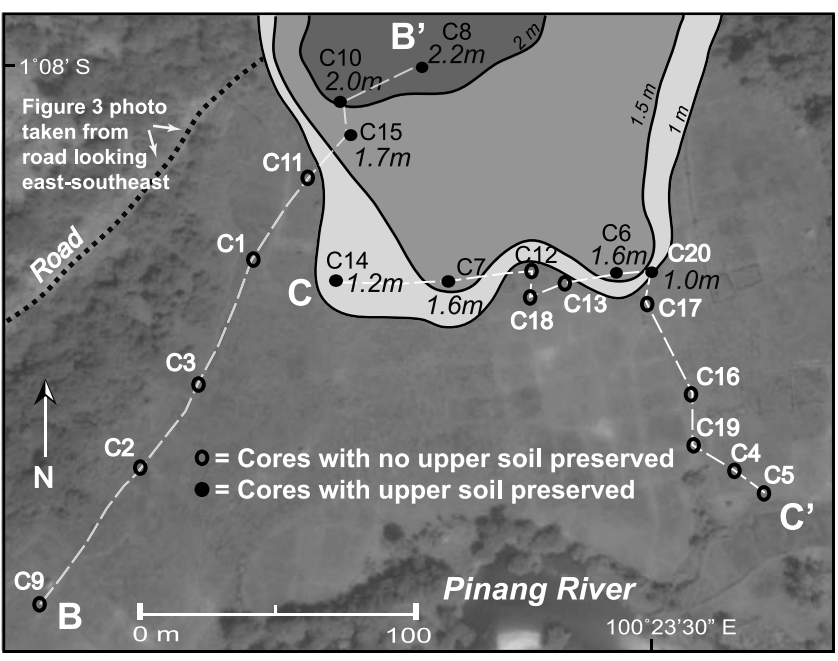

Figure 6. Location of cores containing the upper buried soil. The cores containing the upper buried soil are included in a contour map showing the depth from the surface (relative to MTL) of the upper contact of the upper buried soil, shown in italics below the core number. Figure 3 photograph was taken looking east-southeast from the road overlooking the core transects.

isostatic processes would be expected to result in gradual lithostratigraphic transitions consisting of a thick aggrading mangrove soil sequence [Nelson et al., 1996]. The $>20 \mathrm{~cm}$ of accumulated sediment between the lowest and the middle buried soil suggests a prolonged submergence during which the depositional environment was significantly different. The gradational upper contact from the mud to the middle buried soil illustrates the interseismic strain accumulation that results in the gradual uplift of the coast and RSL fall.

[25] There are two possible explanations for the burial of the upper soil. The first is that the soil was buried by coseismic subsidence, perhaps associated with the A.D. 1797 and 1833 earthquakes. The contacts separating the upper buried soil and overlying mud are sharp in most cores, consistent with abrupt submergence of the soil and a sudden change in depositional environment. Although variable, the geochemistry results suggest an increase in the influence of marine sourced organic matter in the mud overlying the soil.

[26] Although we cannot discount the possibility of coseismic burial of the upper soil, the majority of evidence gathered suggests an alternative method of burial. The upper soil has an average elevation of $2 \mathrm{~m}$ MTL and was buried sometime after 1480 A.D. Thus, in the context of regional RSL change, it is likely that late Holocene emergence of the coast had left the Sungai Pinang floodplain too high for coseismic burial of the upper soil. Observations of Holocene RSL change for southeast Asia [Geyh et al., 1979; Scoffin and Le Tissier, 1998; Hanebuth et al., 2000; Horton et al., 2005] indicate a gradual fall in RSL from $\sim 3000$ cal year B.P. This suggests that the younger-than-A.D. 1480 upper buried soil has been isolated from sea level incursion for thousands of years. Therefore, it is unlikely that a late Holocene rupture along the Mentawai segment of the megathrust produced enough subsidence ( $>2 \mathrm{~m}$ is needed) to submerge the upper soil horizon at the foot of the highlands.
[27] An alternative hypothesis for the origin of burial of the upper soil is river inundation. A contour map of the elevation of the upper contact of the upper buried soil shows the soil is only preserved near the base of the highlands that border the study area (Figure 6). We do not document the upper buried soil in low elevation cores along the Pinang River and instead find a higher concentration of medium to coarse-grained sand in the upper sections of cores 16, 19, and 5. It is likely that the higher relative elevation of the upper buried soil at the foot of the highlands protected it from the flooding of the river during the late Holocene, allowing the soil to develop at the foot of the highlands on a topographically subdued alluvial fan until deposition from one or several large floods buried the soil.

\section{Preservation of Subsidence Events}

[28] In order to preserve a complete record of subsidence stratigraphy in coastal lowlands, the abrupt coseismic rises in RSL that occur as part of each subduction zone earthquake cycle must coincide with a long-term, gradual rise in RSL over millennial timescales (Figure 7). The absence of a late Holocene earthquake record in the Sungai Pinang area is the result of the net emergence of the coast of West Sumatra during the late Holocene [Horton et al., 2005]. The late Holocene fall in regional RSL prevented the formation of the accommodation space that is necessary to preserve subsidence stratigraphy.

[29] A variety of evidence illustrates that the coast has been emergent since $\sim 3000$ years B.P. and the coastline has not prograded significantly in the late Holocene. The modern coastal plain abuts against wave-cut notches observed $250 \mathrm{~m}$ inland from the modern shoreline at elevation $3.5-4.3 \mathrm{~m}$ relative to modern MTL. We infer these wave-cut notches were formed at the time of the mid-Holocene highstand and that the modern coastal plain emerged after the highstand. Alternatively, the raised wave-cut notches could be associated with the stage 5e sea level highstand. But two observations argue against the alternative possibility. First, the raised wave-cut notches are, in both elevation and position, exactly graded to the modern coastal plain that aggraded during Holocene RSL rise; the notches are at the inland margin of the coastal plain and are only a few meters higher than modern high tide levels. Second, an extensive compilation [Kopp et al., 2009] of local RSL histories indicates that global sea level peaked at least $6.6 \mathrm{~m}$ higher than present and was likely as high as $8.0 \mathrm{~m}$ above present at stage 5e time. Such stage 5e sea level magnitudes make it unlikely that the notches that are 3.5-4.3 $\mathrm{m}$ above MTL in our study are associated with the stage 5 e highstand.

[30] To test whether the buried soils were distributed laterally cores D and E were collected $500 \mathrm{~m}$ seaward of the study area. The cores yielded a sequence of mud and organic layers but no evidence of buried soils. We did not observe inset terraces or beach ridge sequences seaward of our study site that preserve younger records because the sediment starved coastline, which is not fed by any major rivers and is bordered on both sides by rocky headlands, has not prograded significantly in the late Holocene.

[31] The two subsidence events (4200 and 3100 cal year B.P.) we documented in the stratigraphic record of the coastal lowland of Sungai Pinang occurred during Holocene 


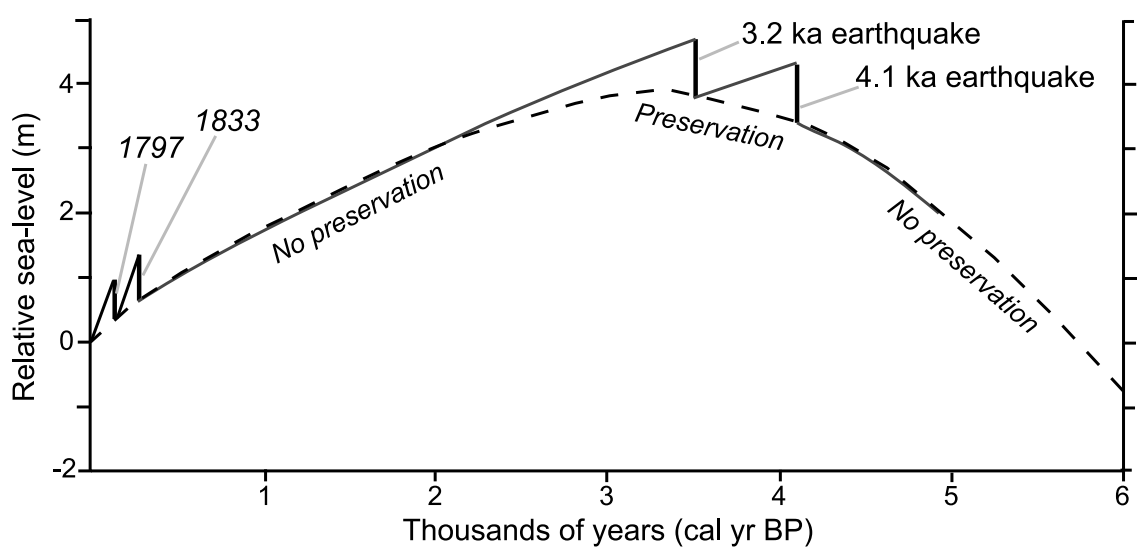

Figure 7. A simplified regional relative sea level (RSL) curve for Padang (West Sumatra) showing midHolocene RSL highstand (dashed line). Solid line represents well-constrained RSL trend and sudden rises in RSL from coseismic subsidence events. 'Preservation' delineates the time window during which time coseismic subsidence is preserved by buried soils. 'No preservation' delineates time spans when coseismic subsidence is not preserved in coastal stratigraphic sequences. The 1797 and 1833 earthquakes are known, historic earthquakes that were not preserved.

RSL rise in Southeast Asia. The early to mid-Holocene rise in RSL that made the preservation of coseismic events possible is accounted for by the eustatic contribution to RSL during the final stage of deglaciation [Milne et al., 2005]. A prominent feature of southeast Asia Holocene sea level records is the mid-Holocene highstand [Geyh et al., 1979; Tjia, 1996; Scoffin and Le Tissier, 1998; Hanebuth et al., 2000], which in Western Sumatra, varies in timing and magnitude from 3000 to 5000 cal years B.P., and +6 to $+2 \mathrm{~m}$ above present-day sea levels [Horton et al., 2005].

[32] We infer that the lack of pre-4200 years B.P. events preserved in the lowest aggrading soil is likely the result of rapid $(\sim 5.5 \mathrm{~mm} / \mathrm{yr})$ early to mid-Holocene sea level rise from $\sim 9000$ years B.P. that allowed mangrove vegetation to keep pace [Morris et al., 2002; Kirwan and Guntenspergen, 2010], but did not create the lasting submergence that occasions mud deposition in a tidal flat. Instances of coseismic subsidence were not preserved in the coastal stratigraphic record as eustatic RSL rose rapidly and mangrove vegetation kept pace. Alternatively, there may have been instances of preservation of coseismic subsidence events in pre-4200 years B.P. deposits during rapid RSL rise, but those deposits would have been seaward of our paleoseismic site and either eroded in the wave zone during RSL rise or buried by prograding coastal clastic deposits.

[33] The coseismic subsidence that buried the thick lowest soil occurred as the eustatic contribution to RSL diminished in the mid Holocene [Mitrovica and Milne, 2002]. As a result of the more gradual RSL rise, mud was able to accumulate above the lowest soil immediately after coseismic subsidence. As interseismic strain raised the intertidal mud back into mangrove elevations, the middle buried soil accumulated. Unlike the lowest soil, the middle soil aggraded slowly due to gradual RSL rise and the soil is thinner. But, similar to the lowest buried soil, the perfect combination of coseismic subsidence and slow sea level rise allowed mud deposition, and hence preservation of the middle buried soil. The wave cut notch observed inland suggests that the mid-Holocene highstand reached about 3.5-4.3 m above MTL before sea level rise slowed and then began to fall.
Thus, our paleoseismic data do not capture any post 3000 cal year B.P. earthquakes, including the historical earthquakes of 1797 and 1833. Paleoseismic data do not record post $3 \mathrm{ka}$ earthquakes because RSL has been gradually falling during the late Holocene at $\sim 1 \mathrm{~mm} / \mathrm{yr}$, a fall driven by ocean siphoning, a process driven by the flux of meltwater from far-field equatorial regions into areas vacated by subsiding forebulges at the periphery of deglaciation centers [Mitrovica and Milne, 2002; Milne et al., 2005].

\section{Subduction Zone Earthquake Recurrence}

[34] We document two subduction zone earthquakes on the Mentawai segment that are roughly 1000 years apart. These earthquakes were large events that subsided the coastline sufficiently to be preserved in the coastal wetland record. Following the suggestion of Sieh et al. [2008], it is possible that each of these earthquakes may be culminating supercycle earthquakes that were preceded by smaller subduction zone earthquakes in the preceding 1000 years. These smaller earthquakes would have involved commensurately more limited rupture parches, and the earthquakes did not leave a paleoseismic record in subsidence stratigraphy. Therefore the 4200 and 3100 cal years B.P. earthquakes may be the largest earthquakes in this time interval to rupture the Mentawai segment, but not the only earthquakes to do so.

\section{Conclusions}

[35] The coastal lowlands of western Sumatra preserve evidence of two Holocene ruptures (4200 and 3100 cal years B.P.) of the Mentawai segment of the Sunda megathrust. The earthquakes are represented by laterally extensive buried soils within the Sungai Pinang coastal lowland. These ruptures of the megathrust resulted in coseismic subsidence of the coastline that inundated existing marsh mangrove soils and buried them with fine-grained intertidal mud. In equatorial sites such as the coast of West Sumatra, the rise in RSL up to the mid Holocene created the accommodation 
space necessary for the preservation of a robust record of mid-Holocene earthquakes, but a fall in RSL since the midHolocene highstand ( 3000 years B.P.) precluded the preservation of late Holocene subsidence stratigraphy.

[36] Acknowledgments. We thank D. Natawidjaja and Bambang Suwargadi for logistical support and K. Sieh and L. Ely for helpful discussions. B. Atwater and R. Briggs provided constructive reviews that contributed substantially to improving the manuscript. This work was supported by funding from National Science Foundation (EAR 0809392, 0809417, 0809625) awarded to C. Rubin, B. Horton, and H. Kelsey. Additional support was provided by Central Washington University, Lembaga Ilmu Pengetahuan Indonesia (LIPI), and National Ocean Sciences Accelerator Mass Spectrometry Facility (NOSAMS). The paper is a contribution to IGCP project 588 and EOS contribution number 26.

\section{References}

Ambler, J. W., J. Alcal-Herrera, and R. Burke (1994), Trophic roles of particle feeders and detritus in a mangrove island prop root ecosystem, Hydrobiologia, 292-293, 437-446, doi:10.1007/BF00229970.

Atwater, B. F. (1987), Evidence for great earthquakes along the outer coast of Washington state, Science, 236, 942-944, doi:10.1126/science. 236.4804.942.

Atwater, B. F., and E. Hemphill-Haley (1997), Recurrence intervals for great earthquakes of the past 3500 years at northeastern Willapa Bay, Washington, U.S. Geol. Surv. Prof. Pap., 1576, 108 pp.

Bock, Y., L. Prawirodirdjo, J. F. Genrich, C. W. Stevens, R. McCaffrey, C. Subarya, S. S. O. Puntodewo, and E. Calais (2003), Crustal motion in Indonesia from Global Positioning System measurements, J. Geophys. Res., 109(B8), 2367, doi:10.1029/2001JB000324.

Bosche, J. H. A. (1988), The Quaternary deposits in the coastal plains of Southern Perak, Peninsula Malaysia, $Q G / 1$, Geol. Surv. of Malaysia, Kuala Lumpur.

Bouillon, S., R. Connolly, and S. Y. Lee (2008), Organic matter exchange and cycling in mangrove ecosystems: Recent insights from stable isotope studies, J. Sea Res., 59, 44-58, doi:10.1016/j.seares.2007.05.001.

Briggs, R., et al. (2006), Deformation and slip along the Sunda megathrust during the giant Nias-Simeulue earthquake of March 2005, Science, 311 1897-1901, doi:10.1126/science.1122602.

Bronk Ramsey, C. (2009), Bayesian analysis of radiocarbon dates, Radiocarbon, 51(1), 337-360.

Bürgmann, R. (2009), Earthquakes: Imperfect dominoes, Nat. Geosci., 2, 87-88, doi:10.1038/ngeo422.

Cisternas, M., et al. (2005), Predecessors of the giant 1960 Chile earthquake, Nature, 437, 404-407, doi:10.1038/nature03943.

Combellick, R. A. (1986), Chronology of late-Holocene earthquakes in southcentral Alaska: Evidence from buried organic soils in upper Turnagain Arm, Geol. Soc. Am. Abstr. Programs, 18(6), 569.

Ellison, J. C. (1989), Pollen analysis of mangrove sediments as a sea level indicator. Assessment from Tongatapu, Tonga, Palaeogeogr. Palaeoclimatol. Palaeoecol., 74, 327-341, doi:10.1016/0031-0182(89) 90068-0.

Ellison, J. C. (2005), Holocene palynology and sea-level change in two estuaries in Southern Irian Jaya, Palaeogeogr. Palaeoclimatol. Palaeoecol., 220, 291-309, doi:10.1016/j.palaeo.2005.01.008.

Engelhart, S. E., B. P. Horton, D. H. Roberts, C. L. Bryant, and D. R. Corbett (2007), Mangrove pollen of Indonesia and its suitability as a sea-level indicator, Mar. Geol., 242(1-3), 65-81, doi:10.1016/j.margeo.2007.02.020.

Genrich, J. F., Y. Bock, R. McCaffrey, L. Prawirodirdjo, C. W. Stevens, S. S. O. Puntodewo, C. Subarya, and S. Wdowinski (2000), Distribution of slip at the northern Sumatran fault system, J. Geophys. Res., 105, 28,327-28,341, doi:10.1029/2000JB900158.

Geyh, M. A., H. Streif, and H. Kudrass (1979), Sea-level changes during the late Pleistocene and Holocene in the Strait of Malacca, Nature, 278, 441-443, doi:10.1038/278441a0.

Grindrod, J. (1985), The palynology of mangroves on a prograded shore, Princess Charlotte Bay, north Queensland, Australia, J. Biogeogr., 12, 323-348, doi: $10.2307 / 2844865$.

Grindrod, J. (1988), The palynology of Holocene mangrove and saltmarsh sediments, particularly in northern Australia, Rev. Palaeobot. Palynol., 55, 229-245, doi:10.1016/0034-6667(88)90088-7.

Hamilton, S., and I. Shennan (2005), Late Holocene great earthquakes and relative sea-level change at Kenai, southern Alaska, J. Quaternary Sci., 20(2), 95-111, doi:10.1002/jqs.903.
Hanebuth, T., K. Stattegger, and P. M. Grootes (2000), Rapid flooding of the Sunda Shelf: A late-glacial sea-level record, Science, 288, 1033-1035, doi:10.1126/science.288.5468.1033.

Hawkes, A., B. Horton, A. Nelson, C. Vane, and Y. Sawai (2011), Coastal subsidence in Oregon, USA, during the giant Cascadia earthquake of AD 1700, Quat. Sci. Rev., 30(3-4), 364-376, doi:10.1016/j.quascirev. 2010.11 .017$.

Hayward, B. W., U. Cochran, K. Southall, E. Wiggins, H. R. Grenfell, A. Sabaa, P. R. Shane, and R. Gehrels (2004), Micropalaeontological evidence for the Holocene earthquake history of the eastern Bay of Plenty, New Zealand, and a new index for determining the land elevation record, Quat. Sci. Rev., 23(14-15), 1651-1667, doi:10.1016/j.quascirev. 2004.01.010.

Horton, B. P., P. L. Gibbard, G. M. Milne, R. J. Morley, C. Purintavaragul, and J. M. Stargardt (2005), Holocene sea-levels and palaeoenvironments, Malay-Thai Peninsula, southeast Asia, J. Asian Earth Sci., 25, 29-43.

Horton, B. P., Y. Zong, C. Hillier, and S. Engelhart (2007), Diatoms from Indonesian mangroves and their suitability as sea-level indicators for tropical environments, Mar. Micropaleontol., 63(3-4), 155-168, doi:10.1016/j.marmicro.2006.11.005.

Jankaew, K., B. F. Atwater, Y. Sawai, M. Choowong, T. Charoentitirat, M. E. Martin, and A. Prendergast (2008), Medieval forewarning of the 2004 Indian Ocean tsunami in Thailand, Nature, 455(7217), 1228-1231.

Kamaludin, H. (1993), The changing mangrove shorelines in Kuala Kurau, Peninsular Malaysia, Sediment. Geol., 83(3-4), 187-197, doi:10.1016/ 0037-0738(93)90012-T.

Kelsey, H. M., R. C. Witter, and E. Hemphill-Haley (2002), Plate-boundary earthquakes and tsunamis of the past $5500 \mathrm{yr}$, Sixes River estuary, southern Oregon, Geol. Soc. Am. Bull., 114, 298-314, doi:10.1130/ 0016-7606(2002)114<0298:PBEATO>2.0.CO;2.

Kemp, A. C., C. H. Vane, B. P. Horton, and S. J. Culver (2010), Stable carbon isotopes as potential sea-level indicators in salt marshes, North Carolina, USA, Holocene, 20, 623-636, doi:10.1177/0959683609354302.

Kirwan, M. L., and G. R. Guntenspergen (2010), Influence of tidal range on the stability of coastal marshland, J. Geophys. Res., 115, F02009, doi:10.1029/2009JF001400

Kopp, R. E, F. J. Simons, J. X. Mitrovica, A. C. Maloof, and M. Oppenheimer (2009), Probabilistic assessment of sea level during the last interglacial, Nature, 462, 863-867, doi:10.1038/nature08686.

Ku, H. W., Y. G. Chen, P. S. Chan, H. C. Liu, and C. C. Lin (2007), Paleoenvironmental evolution as revealed by analysis of organic carbon and nitrogen: A case of coastal Taipei Basin in Northern Taiwan, Geochem. $J ., 41,111-120$, doi:10.2343/geochemj.41.111.

Lamb, A. L., G. P. Wilson, and M. J. Leng (2006), A review of coastal palaeoclimate and relative sea-level reconstructions using $\delta^{13} \mathrm{C}$ and $\mathrm{C} / \mathrm{N}$ ratios in organic material, Earth Sci. Rev., 75(1-4), 29-57, doi:10.1016/j.earscirev.2005.10.003.

Lamb, A. L., C. H. Vane, G. P. Wilson, J. G. Rees, and V. L. Moss-Hayes (2007), Assessing d13C and $\mathrm{C} / \mathrm{N}$ ratios from organic material in archived cores as Holocene sea-level and palaeoenvironmental indicators in the Humber Estuary, UK, Mar. Geol., 244, 109-128, doi:10.1016/ j.margeo.2007.06.012.

Lay, T., et al. (2005), The great Sumatra-Andaman earthquake of 26 December 2004, Science, 308, 1127-1133, doi:10.1126/science. 1112250 .

Marchand, C., J. R. Disnar, E. Lallier-Verges, and N. Lottier (2005), Early diagenesis of carbohydrates and lignin in mangrove sediments subject to variable redox conditions (French Guiana), Geochim. Cosmochim. Acta, 69, 131-142, doi:10.1016/j.gca.2004.06.016.

Matthijs, S., J. Tack, D. van Speybroeck, and N. Koedam (1999), Mangrove species zonation and soil redox state, sulphide concentrate and salinity in Gazi Bay (Kenya), a preliminary study, Mangroves Salt Marshes, 3, 243-249, doi:10.1023/A:1009971023277.

McCloskey, J., D. Lange, F. Tilmann, S. S. Nalbant, A. F. Bell, D. H. Natawidjaja, and A. Rietbrock (2010), The September 2009 Padang earthquake, Nat. Geosci., 3, 70-71, doi:10.1038/ngeo753.

Michel, G. W., et al. (2001), Crustal motion and block behaviour in SE-Asia from GPS measurements, Earth Planet. Sci. Lett., 187, 239-244, doi:10.1016/S0012-821X(01)00298-9.

Milne, G. A., A. J. Long, and S. E. Bassett (2005), Modeling Holocene relative sea-level observations from the Caribbean and South America, Quat. Sci. Rev., 24(10-11), 1183-1202, doi:10.1016/j.quascirev. 2004.10.005.

Mitrovica, J., and G. Milne (2002), On the origin of late Holocene sea-level highstands within equatorial ocean basins, Quat. Sci. Rev., 21(20-22), 2179-2190, doi:10.1016/S0277-3791(02)00080-X.

Monecke, K., W. Finger, D. Klarer, W. Kongko, B. G. McAdoo, A. L. Moore, and S. U. Sudrajat (2008), A 1,000-year sediment record of tsunami recurrence in northern Sumatra, Nature, 455(7217), 1232-1234. 
Morris, J. T., P. V. Sundareshwar, C. T. Nietch, B. Kjerfve, and D. R. Cahoon (2002), Responses of coastal wetlands to rising sea level, Ecology, 83(10), 2869-2877, doi:10.1890/0012-9658(2002)083[2869: ROCWTR]2.0.CO;2.

Nalbant, S., S. Steacy, K. Sieh, D. Natawidjaja, and J. McCloskey (2005), Earthquake risk on the Sunda trench, Nature, 435, 756-757, doi:10.1038/ nature435756a.

Natawidjaja, D., K. Sieh, M. Chlieh, J. Galetzka, B. Suwargadi, H. Cheng, R. Edwards, J. Avouac, and S. Ward (2006), Source parameters of the great Sumatran megathrust earthquakes of 1797 and 1833 inferred from coral microatolls, J. Geophys. Res., 111, B06403, doi:10.1029/ 2005JB004025.

Natawidjaja, D., K. Sieh, J. Galetzka, B. Suwargadi, H. Cheng, R. Edwards, and M. Chlieh (2007), Interseismic deformation above the Sunda Megathrust recorded in coral microatolls of the Mentawai islands, West Sumatra, J. Geophys. Res., 112, B02404, doi:10.1029/ 2006JB004450.

Nelson, A. R., K. Kashima, and L. Bradley (2009), Fragmentary evidence of great-earthquake subsidence during Holocene emergence, Valdivia Estuary, South Central Chile, Bull. Seismol. Soc. Am., 99(1), 71-86, doi: $10.1785 / 0120080103$

Nelson, A. R., et al. (1995), Radiocarbon evidence for extensive plateboundary rupture about 300 years ago at the Cascadia subduction zone, Nature, 378, 371-374, doi:10.1038/378371a0.

Nelson, A. R., I. Shennan, and A. J. Long (1996), Identifying coseismic subsidence in tidal-wetland stratigraphic sequences at the Cascadia subduction zone of western North America, J. Geophys. Res., 101, 6115-6135, doi:10.1029/95JB01051.

Nelson, A. R., Y. Sawai, A. E. Jennings, L. Bradley, L. Gerson, B. L. Sherrod, J. Sabean, and B. P. Horton (2008), Great-earthquake paleogeodesy and tsunamis of the past 2000 years at Alsea Bay, centra Oregon coast, USA, Quat. Sci. Rev., 27(7-8), 747-768, doi:10.1016/j. quascirev.2008.01.001.

Newcomb, K. R., and W. R. McCann (1987), Seismic history and seismotectonics of the Sunda Arc, J. Geophys. Res., 92, 421-439, doi:10.1029/ JB092iB01p00421.

Ovenshine, A. T., D. E. Lawson, and S. R. Bartsch-Winkler (1976), The Placer River silt-An intertidal deposit caused by the 1964 Alaska earthquake, J. Res. U.S. Geol. Surv., 4(2), 151-162.

Prawirodirdjo, L., and Y. Bock (2004), Instantaneous global plate motion model from 12 years of continuous GPS observations, J. Geophys. Res., 109, B08405, doi:10.1029/2003JB002944.

Reimer, P. J., et al. (2004), IntCal04 terrestrial radiocarbon age calibration, 0-26 cal kyr B.P, Radiocarbon, 46(3), 1029-1058.

Sawai, Y., B. P. Horton, and T. Nagumo (2004), The development of a diatom-based transfer function along the Pacific coast of eastern Hokkaido, northern Japan-an aid in paleoseismic studies of the Kuril subduction zone, Quat. Sci. Rev., 23(23-24), 2467-2483, doi:10.1016/ j.quascirev.2004.05.006

Scoffin, T. P., and M. D. A. Le Tissier (1998), Late Holocene sea leve and reef-flat progradation, Phuket, South Thailand, Coral Reefs, 17(3), 273-276, doi:10.1007/s003380050128.

Sieh, K., and D. Natawidjaja (2000), Neotectonics of the Sumatran fault, Indonesia, J. Geophys. Res., 105, 28,295-28,326, doi:10.1029/ 2000JB900120.
Sieh, K., D. Natawidjaja, A. Meltzner, C. Shen, H. Cheng, K. Li, B. Suwargadi, J. Galetzka, B. Philibosian, and R. L. Edwards (2008), Earthquake supercycles inferred from sea-level changes recorded in the corals of West Sumatra, Science, 322, 1674-1678, doi:10.1126/science. 1163589.

Somboon, J. R. P., and N. Thiramongkol (1992), Holocene highstand shoreline of the Chao Phyraya delta, Thailand, J. Southeast Asian Earth Sci., 7, 53-60, doi:10.1016/0743-9547(92)90014-3.

Streif, H. (1979), Cyclic formation of coastal deposits and their indications of vertical sea-level changes, Oceanis, 5, 303-306.

Subarya, C., M. Chlieh, L. Prawirodirdjo, J. P. Avouac, Y. Bock, K. Sieh, A. Meltzner, D. Natawidjaja, and R. McCaffrey (2006), Plate-boundary deformation associated with the great Sumatra-Andaman earthquake, Nature, 440, 46-51, doi:10.1038/nature04522.

Tjia, H. D. (1996), Sea-level changes in the tectonically stable Malay-Thai Peninsula, Quat. Int., 31, 95-101, doi:10.1016/1040-6182(95)00025-E.

Törnqvist, T. E., D. J. Wallace, J. E. A. Storms, J. Wallinga, R. L. Van Dam, M. Blaauw, M. S. Derksen, C. J. W. Klerks, C. Meijneken, and E. M. A. Snijders (2008), Mississippi Delta subsidence primarily caused by compaction of Holocene strata, Nat. Geosci., 1, 173-176, doi:10.1038/ngeo129.

Troels-Smith, J. (1955), Characterization of Unconsolidated Sediments, Geol. Surv. Den. IV, vol. 3, 72 pp., C.A. Reitzel, Copenhagen.

Whitten, T., S. J. Damanik, J. Anwar, and N. Hisyam (1997), The Ecology of Sumatra, 583 pp., Tuttle, North Clarendon, Vt.

Wilson, G. P., A. L. Lamb, M. J. Leng, S. Gonzalez, and D. Huddart (2005), $\delta^{13} \mathrm{C}$ and $\mathrm{C} / \mathrm{N}$ as potential coastal palaeoenvironmental indicators in the Mersey Estuary, UK, Quat. Sci. Rev., 24(18-19), 2015-2029, doi:10.1016/j.quascirev.2004.11.014

Zachariasen, J., K. Sieh, F. W. Taylor, R. L. Edwards, and W. S. Hantoro (1999), Submergence and uplift associated with the giant 1833 Sumatran subduction earthquake: Evidence from coral microatolls, J. Geophys. Res., 104, 895-919, doi:10.1029/1998JB900050.

Zachariasen, J., K. Sieh, F. Taylor, and W. Hantoro (2000), Modern vertical deformation at the Sumatran subduction zone: Paleogeodetic insights from coral microatolls, Bull. Seismol. Soc. Am., 90, 897-913, doi:10.1785/0119980016.

S. Bradley, Department of Earth Sciences, University of Bristol, Bristol BS8 1TH, UK

M. Daryono and C. M. Rubin, Department of Geology, Central Washington University, Ellensburg, WA 98926, USA.

T. Dura, B. P. Horton, and C. G. Pre, Sea Level Research, Department of Earth and Environmental Science, University of Pennsylvania, Philadelphia, PA 19104, USA. (dura@sas.upenn.edu)

A. Hawkes, Woods Hole Oceanographic Institute, 266 Woods Hole Rd. Woods Hole, MA 02543, USA.

H. M. Kelsey and T. Ladinsky, Department of Geology, Humboldt State University, Arcata, CA 95521, USA.

C. H. Vane, British Geological Survey, Kingsley Dunham Centre, Nottingham, NG12 5GG, UK. 